Diabetologia $9,505-508(1973)$

(C) by Springer-Verlag 1973

\title{
Enhanced Intestinal Fat Absorption in Diabetic Chinese Hamsters
}

\author{
T.M. Parkinson \\ Diabetes and Atherosclerosis Research, The Upjohn Company, Kalamazoo, Michigan 49001 U.S.A. \\ Received: April 24, 1973, and in revised form: July 30, 1973
}

Summary. Intestinal absorption of glyceryl tri-[1-14 C]oleate and $\left[1{ }^{14} \mathrm{C}\right]$-oleic acid, measured by serial determinations of blood radioactivity after oral administration of the compounds in peanut oil, was significantly greater in non-ketotic diabetic Chinese hamsters than in nondiabetic controls. Incorporation of $\left[1{ }^{14} \mathrm{C}\right]$-oleic acid into tissue lipids by jejunal slices in vitro was equal in both groups on a unit tissue weight basis. The data suggest that intraluminal hydrolysis does not differ between diabetic and non-diabetic animals. Overall uptake of free fatty acids may be enhanced in diabetics as a consequence of increased small intestinal mass.

Key words: Chinese hamster, Cricetulus griseus, diabetes, intestinal absorption, triglyceride, fatty acid, blood radioactivity, intestinal lipid synthesis.
Intestinal absorption of sugars and amino acids is enhanced in alloxan or streptozotocin-induced diabetic rats $[1-5]$ and in humans with juvenile onset diabetes [6]. Diet balance studies indicate that alloxan diabetic rats absorb fat more efficiently than non-diabetic controls [7]. However, direct measurements of fat absorption in diabetic experimental animals do not appear to have been carried out. Fat absorption in humans with poorly controlled diabetes of long duration frequently is impaired, as evidenced clinically by diabetic steatorrhea. Corsini et al. [8] reported that intestinal absorption of ${ }^{131} \mathrm{I}$ - and ${ }^{125} \mathrm{I}$-labelled triolein and oleic acid is decreased in diabetic subjects, independently of xylose absorption. In order to evaluate fat absorption in experimental diabetic animals by similar radioisotope techniques, absorption of ${ }^{14} \mathrm{C}$ labelled triolein and oleic acid was determined in Chinese hamsters.

\section{Methods \\ Animals}

Animals of both sexes were selected for study from the Upjohn colony of Chinese hamsters described previously by Gerritsen and Dulin [9]. Non-ketotic diabetic animals were characterized by a consistent Tes-Tape ${ }^{\circledR}$ value of $+\mathbf{4}$ for urine glucose. Glucosuria correlates well with blood sugar in these animals and is an acceptable measurement of diabetes [10]. Diabetic animals were matched with non-diabetic animals of the same sex and approximate age. All animals were maintained on Purina Mouse Breeder Chow and fasted for $24 \mathrm{~h}$ before use. Body weights of fasted diabetic and non-diabetic animals did not differ significantly.

\section{Intestinal Absorption in vivo}

Each animal received via stomach tube either $2 \mu \mathrm{Ci}$ glyceryl tri-[1-14 $\mathrm{C}]$-oleate (sp act $41 \mathrm{mCi} / \mathrm{mmol}$ ) or $2 \mu \mathrm{Ci}$ $\left[1{ }^{14} \mathrm{C}\right]$-oleic acid (sp act $59.7 \mathrm{mCi} / \mathrm{mmol}$ ) (Amersham/
Searle Corp.) dissolved in $0.2 \mathrm{ml}$ peanut oil. Blood samples were taken from the orbital sinus [11] at intervals up to $8 \mathrm{~h} .25 \mu \mathrm{l}$ of each sample was added immediately to a glass scintillation vial containing $0.2 \mathrm{ml}$ saline using an Eppendorf pipet. One drop of n-octanol was added to prevent foaming and the diluted blood was bleached with $0.2 \mathrm{ml} 30 \%$ hydrogen peroxide. Bleached samples were dissolved in $2 \mathrm{ml}$ Soluene-100 ${ }^{\circledR}$ (Packard Instrument Company, Inc.) and counted in $15 \mathrm{ml}$ of Diotol scintillation fluid [12] in a TriCarb ${ }^{\circledR}$ Model 3375 liquid scintillation spectrometer (Packard Instrument Company, Inc.). Counting efficiency was determined using a $\left[{ }^{14} \mathrm{C}\right]$-toluene standard and appropriate blanks and averaged $71 \%$.

\section{Oleic Acid Incorporation in vitro}

The small intestine was excised under ether anesthesia, rinsed in ice cold saline and everted over a glass rod. Approximately $5 \mathrm{~cm}$ of the proximal jejunum was cut into rings $1-2 \mathrm{~mm}$ wide, excluding segments with visible lymph nodes [13]. Rings from individual diabetic animals and non-diabetic controls were pooled and kept in Krebs-Ringer bicarbonate buffer p.H 7.4, gassed with $95 \% \mathrm{O}_{2}-5 \% \mathrm{CO}_{2}$, at room temperature until used (approximately $10 \mathrm{~min}$ ). Incubation medium was Krebs-Ringer bicarbonate buffer, $\mathrm{pH}$ 7.4, containing $0.7-0.8 \mu \mathrm{Ci}\left[1-{ }^{14} \mathrm{C}\right]$-oleic acid (sp act $59.7 \mathrm{mCi}$ ) (Amersham/Searle Corp.) per $3 \mathrm{ml}$. The oleic acid was dissolved in 2-3 drops ethanol, converted to the sodium salt with 1 drop of $0.1 \mathrm{~N} \mathrm{NaOH}$ and dissolved. in buffer to give the desired final concentration. Five rings of intestine were incubated in $3 \mathrm{ml}$ of medium for $60 \mathrm{~min}$ at $37^{\circ}$ under $95 \% \mathrm{O}_{2}-5 \% \mathrm{CO}_{2}$.

Incubation was stopped by placing the flasks in an ice water bath. Tissue was rinsed in buffer, blotted dry on filter paper and weighed. Rings from each flask were homogenized in glass screw cap tissue grinders (Kontes Glass Co.) in $5 \mathrm{ml}$ chloroform-methanol (2:1, $\mathrm{v} / \mathrm{v})$ and stood for $1.5-2 \mathrm{~h}$. The tubes were centrifuged and the supernatant was removed and washed with 
$2 \mathrm{ml}$ of $0.073 \% \mathrm{MgCl}_{2} .6 \mathrm{H}_{2} \mathrm{O}$. Washed lower organic phase was evaporated under $\mathrm{N}_{2}$ and the residue was redissolved in chloroform-methanol. One $\mathrm{ml}$ was pipetted into scintillation vials, evaporated and dissolved in $15 \mathrm{ml}$ Diotol. The remainder was evaporated, redissolved in a few drops of chloroform-methanol and chromatographed on pre-coated silica gel TLC plates (Brinkmann Instruments, Inc.) in hexane-ethyl etheracetic acid $(90: 10: 1, \mathrm{v} / \mathrm{v} / \mathrm{v})$. Spots were detected by iodine vapour and those corresponding to phospholipids and monoglycerides (origin), diglycerides, cholesterol, fatty acids, triglycerides and cholesterol esters were identified by chromatographing known standards on the same plates. Spots were scraped into scintillation vials, shaken with $15 \mathrm{ml}$ Diotol containing $3 \%$ water for $1 \mathrm{~h}$ to elute lipids from the silica gel and counted. Counting efficiency for both the Diotol and Diotol + $3 \%$ water systems was determined using a $\left[{ }^{14} \mathrm{C}\right]$-toluene standard and averaged 87 and $85 \%$, respectively.

\section{Statistical Methods}

Because of unequal variances in the diabetic and non-diabetic groups, intestinal absorption of glyceryl trioleate and oleic acid was evaluated by nonparametric statistics using the Wilcoxon rank sum test [14]. Oleic acid incorporation data were evaluated by a oneway analysis of variance using Dunnett's $t$ test [15].

\section{Results}

\section{Intestinal Absorption in vivo}

Radioactivity from administered glyceryl tri-[1${ }^{14} \mathrm{C}$ ]-oleate appeared in the blood of diabetio hamsters significantly faster than in non-diabetic controls through the $3 \mathrm{~h}$ sampling period (Fig. 1). Peak blood levels occurred between 3 and $4 \mathrm{~h}$ in both groups. Total area under the radioactivity-time curve from. $0-8 \mathrm{~h}$ was approximately 3 times greater in diabetics. Inspection of the total curve areas for each animal showed no correlation between triglyceride absorption and body weight over the weight range of $17.8-31.7 \mathrm{~g}$.

Intraluminal hydrolysis of long-chain fatty acid triglycerides by pancreatic lipase precedes fatty acid absorption [16]. In order to distinguish at least indirectly between possible enhanced hydrolysis of glyceryl tri-[1-14 $\mathrm{C}]$-oleate and enhanced absorption of released $\left[1-{ }^{14} \mathrm{C}\right]$-oleic acid, absorption of administered free fatty acid was determined. Radioactivity was significantly higher in diabetic animals than in nondiabetics over the entire $8 \mathrm{~h}$ sampling period and was maximal at $3 \mathrm{~h}$ in both groups (Fig. 2). Total radioactivity was approximately 2.5 times greater in diabetics than in non-diabetics. There was no correlation between absorption and body weight over the weight range of $21.0-38.5 \mathrm{~g}$.
Oleic Acid Incorporation in vitro

Triglycerides are resynthesized from absorbed free fatty acids and 2-monoglycerides prior to being re-

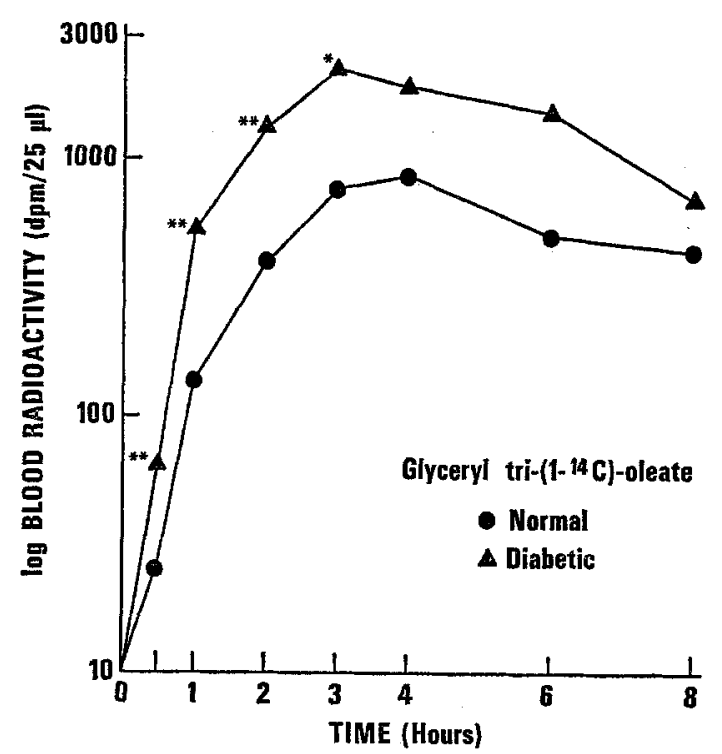

Fig. 1. Absorption of glyceryl-[1-14C]-trioleate by diabetic and normal Chinese hamsters. 10 animals/group. Significant difference between diabetics and normals ${ }^{*} p<0.05$, $*{ }^{*} \mathrm{p}<0.01$.

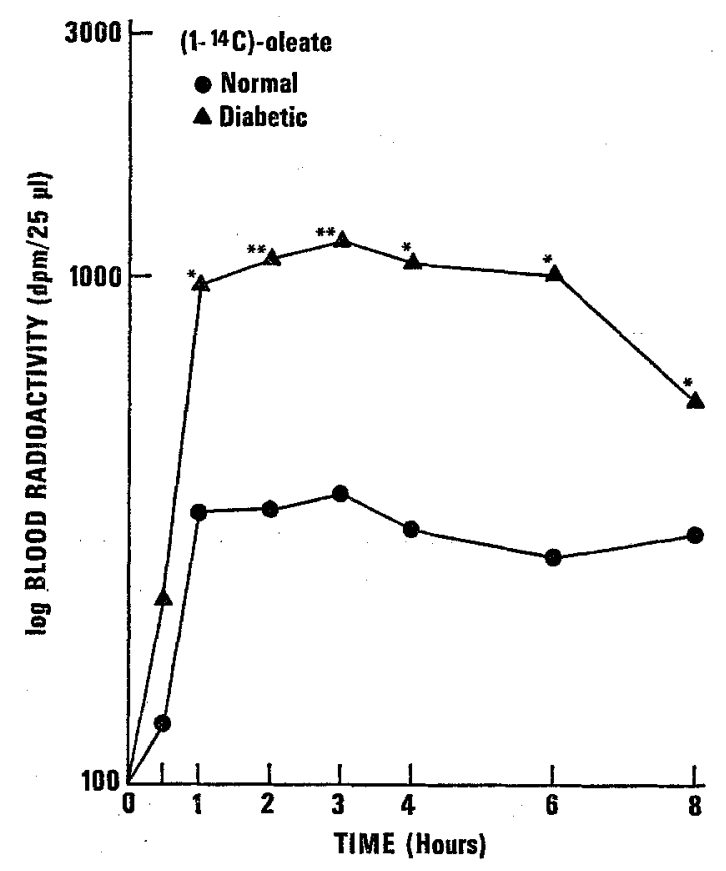

Fig. 2. Absorption of $\left[1-{ }^{14} \mathrm{C}\right]$-oleic acid by diabetic and normal Chinese hamsters. 10 animals/group. Significant difference between diabetics and normals ${ }^{*} \mathrm{p}<0.05$, $* * \mathrm{p}<0.01$.

leased into the lymph in chylomicrons [16]. This intracellular metabolic phase of fat absorption was compared in diabetic and non-diabetic hamsters by determining the incorporation of $\left[1-{ }^{14} \mathrm{C}\right]$-oleic acid into 
triglycerides and other lipid fractions by slices of intestine in vitro. Overall results of three separate experiments indicate no difference in total incorporation per mg wet weight of intestine (Table 1). Incubated and non-incubated intestinal rings were dried in a vacuum desiccator over $\mathrm{P}_{2} \mathrm{O}_{5}$. Water content of both diabetic and non-diabetic tissue was $85 \%$; hence total incorporation also did not differ significantly on a dry tissue weight basis. Distribution of radioactivity in the various lipid fractions was equivalent.

\section{Discussion}

Blood specific radioactivity is not greater in the diabetic animals because of haemoconcentration. Sirek and Sirek [17] reported that haematocrit and total serum protein are identical in non-diabetic and non-ketotic diabetic Chinese hamsters. I also found no significant difference in haematocrits of diabetic and non-diabetic animals used in these studies (diabetics $49 \pm 2.8$, non-diabetics $46 \pm 3.2$, mean $\pm S . D$.$) .$ free oleic acid in diabetic animals indicates that enhanced triolein absorption probably is not solely the result of increased intraluminal hydrolysis, although this may contribute to the overall process. Biochemical [20] and morphological [21, 22] studies have shown that uptake of micellar fatty acids from the intestinal lumen is an energy-independent diffusion process. The kinetic characteristics of the entry step have been described as typical of a saturation phenomenon [23], and hence uptake should depend on total absorptive surface area. In addition Cardell et al. [24] have proposed that intracellular synthesis and sequestration of triglycerides on smooth endoplasmic reticulum maintains the fatty acid diffusion gradient and permits continued absorption. This process also would depend on cell mass.

Therefore, it is possible that enhanced intestinal fat absorption in the diabetic Chinese hamster is a consequence of increased small intestinal mass. Preliminary data indicate diabetic hamster small intestine is larger, expressed as wet weight or percent body weight, than non-diabetic hamster small intestine. If

Table 1. Incorporation of $\left[l_{-14} C\right]$-oleic acid into intestinal lipids by normal and diabetic hamsters.

\begin{tabular}{|c|c|c|c|c|c|c|c|}
\hline \multirow[b]{2}{*}{ Animals } & \multirow{2}{*}{$\begin{array}{l}\text { Total incorporation }{ }^{a} \\
\text { (dpm/mg wet wt) }\end{array}$} & \multirow{2}{*}{$\begin{array}{l}\text { phospholipids + } \\
\text { monoglycerides }\end{array}$} & \multicolumn{5}{|c|}{ Incorporation into lipid classes $(\%)^{\mathrm{b}}$} \\
\hline & & & diglycerides & cholesterol & fatty acids & triglycerides & $\begin{array}{l}\text { cholesterol } \\
\text { esters }\end{array}$ \\
\hline Normal & $1740 \pm 123$ & $15.2 \pm 2.6$ & $1.9+0.2$ & $1.1 \pm 0.4$ & $31.9 \pm 3.6$ & $48.6 \pm 3.4$ & $2.3 \pm 0.7$ \\
\hline Diabetic & $1797 \pm 117$ & $21.2 \pm 3.4$ & $1.9 \pm 0.2$ & $0.9 \pm 0.3$ & $30.5 \pm 5.1$ & $43.8 \pm 2.8$ & $1.8 \pm 0.1$ \\
\hline
\end{tabular}

a Means + SFM. Results of 3 experiments.

b Means \pm SEM. Results of 2 experiments.

In each experiment, pooled slices from 2 normal and 2 diabetic hamsters were incubated in triplicate.

Change in blood radioactivity following a test dose of labelled fat or fatty acid is often used both clinically and in experimental animals as an estimate of fat absorption [18]. Studies of plasma triglyceride hydrolysis and uptake by liver and peripheral tissue have not been done in Chinese hamsters and I assume in interpreting the blood radioactivity curves in the present study that rate of removal of triglycerides, which should be the predominant ${ }^{14} \mathrm{C}$-labelled chemical species, is similar in diabetic and non-diabetic animals. That this is so is suggested by similar shapes of the curves for both groups, but this would have to be confirmed by direct measurement such as oleic acid clearance after intravenous administration. Hence, differences in peak and total radioactivity are attributed to differences in intestinal fat hydrolysis or absorption.

Since absorption of triolein was enhanced rather than decreased, pancreatic lipase secretion does not appear to be impaired in diabetic hamsters. Exocrine pancreatic function has not been evaluated in Chinese hamsters, although decreased plasma insulin response to feeding [9] and decreased beta cell mass and beta cell degranulation [19] suggest endocrine pancreas dysfunction.

Markedly increased absorption of administered this is so, although intracellular incorporation of $\left[1-{ }^{14} \mathrm{C}\right]$-oleic acid into triglycerides did not differ per unit of intestinal weight, incorporation would be expected to be greater overall, leading to enhanced chylomicron formation and release. Such an effect of increased gut size on hexose transport in alloxan- and streptozotocin-induced diabetic rats bas been reported by Schedl and Wilson [4].

Acknowledgement. I thank Mr. T. Honohan for skillful technical assistance.

\section{References}

1. Laszt, L., Vogel, H.: Resorption of glucose from the small intestine of alloxan-diabetic rats. Nature (Lond.) $157,551-552(1946)$

2. Crane, R.K.: An effect of alloxan-diabetes on the active transport of sugars by rat small intestine, in vitro. Biochem biophys. Res. Commun. 4, 436-440 (1961)

3. Olsen, W.A., Rosenberg, I.H.: Intestinal transport of sugars and amino acids in diabetic rats. J. clin. Invest. 49, 96-105 (1970)

4. Schedl, H.P., Wilson, H.D.: Effects of diabetes on intestinal growth and hexose transport in the rat. Amer. J. Physiol. 220, 1739-1745 (1971) 
5. Lal, D., Schedl, H.P.: Regulation of intestinal amino acid transport. Gastroenterol. 64, $758(1973)$

6. Vinnik, I. E., Kern, F., Jr., Sussman, K.E. : The effect of diabetes mellitus and insulin on glucose absorption by the small intestine in man. J. Lab. clin. Med. 66, $131-136(1965)$

7. Schneider, L.E., Schedl, H.P.: Diabetes and intestinal calcium absorption in the rat. Amer. J. Physiol. 223, $1319-1323(1972)$

8. Corsini, G., Gandolfi, E., Bonechi, I., Cerri, B.: Fat absorption in diabetes mellitus. Diabetes 16, $455-461$ (1967)

9. Gerritsen, G.C., Dulin, W.E.: Characterization of diabetes in the Chinese hamster. Diabetologia 3, 74$84(1967)$

10. Dulin, W.E., Gerritsen, G.C.: Interaction of genetics and environment on diabetes in the Chinese hamster as compared with human and other diabetic animal species. In: Nutrition and Diabetes Mellitus. VI. Capri Conference, Capri, 1972. (Eds. Froesch, E.R., Yudkin, J.) Acta Diabetologia Latina 9, Suppl, 1, $48-84$ (1972)

11. Riley, V.: Adaptation of the orbital bleeding technic to rapid serial blood studies. Proc. Soc. exp. Biol. (N.Y.) 104, 751 - 754 (1960)

12. Herberg, R.J.: Determination of carbon-14 and tritium in blood and other whole tissues. Anal. Chem. $32,42-46(1960)$

13. Crane, R.K., Mandelstam, P.: The active transport of sugars by various preparations of hamster intestine. Biochim. biophys. Acta (Amst.) 45, 460-476 (1960)

14. Steel, R.G.D., Torrie, J.H.: Principles and procedures of statistics, pp. 402-403. Now York: McGrawHill Book Co., Inc. 1960

15. Ibid., pp. $111-112$

16. Senior, J.R.: Intestinal absorption of fats. J. Lipid Res. 5, 495-521 (1964)
17. Sirek, O.V., Sirek, A.: The colony of Chinese hamsters of the C.H. Best Institute. A review of experimental work. Diabetologia 3, 65-73 (1967)

18. Wiseman, G.: Absorption from the intestine, pp. 85147. New York: Academic Press, Inc. 1964

19. Carpenter, A.-M., Gerritsen, G.C., Dulin, W.E., Lazarow, A. : Islet and beta cell volumes in diabetic Chinese hamsters and their non-diabetic siblings. Diabetologia 3, $92-96(1967)$

20. Johnston, J.M., Borgström, B.: The intestinal absorption and metabolism of micellar solutions of lipids. Biochim. biophys. Acta (Amst.) 84, 412-423 (1964)

21. Strauss, E., Ito, S. : Autoradiographic and biochemical study of linolenic acid-C ${ }^{14}$ absorption by hamster intestine from mixed micelles in vitro. J. Cell Biol. 27, $101 \mathrm{~A}(1965)$

22. Strauss, E.W.: Electron microscopic study of intestinal fat absorption in vitro, from mixed micelles containing linolenic acid, monoolein, and bile salt. $\mathrm{J}$. Lipid Res. 7, 307-323 (1966)

23. Lyon, I.: Studies on transmural potentials in vitro in relation to intestinal absorption V. Kinetic characteristics of lipid interactions with rat gut. Biochim. biophys. Acta (Amst.) 163, 75-84 (1968)

24. Cardell, R.R., Jr., Badenhausen, S., Porter, K.R.: Intestinal triglyceride absorption in the rat. An electron microscopical study. J. Cell Biol. 34, 123-155 (1967)

Dr. T.M. Parkinson

Diabetes and Atherosclerosis Research

The Upjohn Company

Kalamazoo

Michigan 49001

U.S.A. 